\title{
The Effect of Applying Learning Theory to Horticultural Therapy on Improving Personal Relationships in High School Students with Intellectual Disabilities
}

\author{
lee-Hwa Jang ${ }^{*}$ and Kyung-Hee Han \\ Korean Horticultural Therapy \& Wellbeing Gyeonggi Branch, Suwon 16675, Korea
}

\begin{abstract}
In order to actively apply horticultural therapy to vocational education base schools, this study applied the learning theories based on behaviorism, cognitivism, and constructivism to improve the vocational skills of high school students with intellectual disabilities. The horticultural therapy program was carried out in total 12 sessions with three groups composed of 20 students each: 20 in the control group, 20 in the experimental group with a normal horticultural program, and 20 in the experimental group with a horticultural therapy program which applied the learning theories based on behaviorism, cognitivism, and constructivism. The results were analyzed with SPSS 12.0 using the Interpersonal Negotiation Strategies evaluation tool. The study found that in terms of interpersonal relationship, there was no significant difference between the pre and post tests within each group. However, in the post tests among the three groups, there was no significant difference between control group and experimental group with normal horticultural program $(p=.82)$, but there was a significant difference between the control group and experimental group with the horticultural therapy program applying the learning theories based on behaviorism, cognitivism $(p=.03)$. This proved that the horticultural therapy program applying the learning theories based on behaviorism, cognitivism is effective for improving interpersonal relationship. Ultimately the program is expected to be continuously, and systematically improved and applied as a learning method contributing to developing the basic vocational skills of persons with intellectual disabilities.
\end{abstract}

Keywords: cooperative learning, employee performance, integrated vocational education, sociality enhancement, vocational rehabilitation

\section{Introduction}

Recently the change in the perception of persons with disabilities in the society has brought various changes to the government policies, and led the government to abolish the Act on the Promotion of Education for the Handicapped in 2007 and enact/enforce the Act on Special Education for Persons with Disabilities, etc. in May 2008, developing along with the changes of times over the last decade or so. In 2017, the Lifelong Education Act was amended and laid the groundwork for lifelong education of persons with disabilities. The Moon Jae-in government is making efforts to build a society for both persons with and without disabilities by announcing the 5th Five-Year Plan for Special Education 
(2018-2022) focusing on ensuring internal stability of integrated education and reinforcing career, higher and lifelong education. Among them, the "integrated vocational education base school" is implemented most actively, enabling students subject to special education to receive integrated education at a regular school. This school offers various programs of vocational training to ensure internal stability of career and vocational education focused on field placement, but horticultural activities have low applicability. Thus, it is necessary to develop more active and developmental horticultural programs and seek ways to operate them continuously.

Vocational training pursued by the integrated vocational education base school has various purposes such as interpersonal skills and sociality improvement for job performance beyond just technical training, and such prevocational training of skills is absolutely necessary due to various problems that may cause difficulty in vocational rehabilitation (Lee et al., 2012). In that sense, horticultural activities develop all kinds of vocational potential (Suh and Lee, 2004), improve emotional behavior, interpersonal strategies and vocational interest (Joo, 2013), increase concentration and sociality (B.Y. Kim, 2010), cause learning motives (Kang, 2004), improve job performance skills (Lee, 2011), enhance self-determination, creative personality, career maturity and scholastic achievement (Jung, 2011), reduce adolescent bullying, depression, anxiety and stress while increasing resilience and helping obtain creative job-related knowledge and skills (Noh, 2016), improve self-esteem and school adjustment (Son, 2015), and increase interest and response toward other people's words and actions (Lee et al., 2002), thereby suitable for vocational training at the integrated vocational education base school.

However, even though there are many studies already conducted on the effects of horticultural therapy programs, none of them have actively examined efficient and effective methods of operation.

This study considered that high school students with intellectual disabilities are socially and behaviorally intimidated and fall behind (Park, 2006) due to difficulty in communication (Cho, 2005), slow movement perception (Choi, 1981), low intelligence and lack of cognitive ability. Accordingly, this study implements not just one learning theory but all of learning theories based on behaviorism, cognitivism, and constructivism, pointing out the importance of repeated memory in increasing learning effects (S.Y. Kim, 2010) as well as review cycle (K.L. Kim, 2010).

The learning theory based on behaviorism (direct instruction) induces learning motives with the instructors' enthusiastic attitude and preparations as well as close observation of the subjects and educational stimulation of students. The learning theory based on cognitivism (discovery learning) increases activities and participation through learning by discoveries and arouses interest in class (Kim, 2011), adequately applies to the learners' cognitive structure (Choi, 2004), make them build concepts on their own with interest and spontaneity (Lee, 2004), boosts achievement needs by having learners directly discover, explore and observe (Kim, 2003), thereby arousing interest by providing motives.

Moreover, the learning theory based on constructivism (cooperative learning) forms learning based on the learners' interest as well as inherent experience, and can be properly achieved as a result of self-initiative and voluntary activities as they encounter new things to learn and assimilate with information based on ownership of learning (Kim, 2017). By specifying and applying the three theories to the program in phases, this study verifies that repeated and systematic horticultural learning and various teaching methods help horticultural activities exert positive effects on causing learning motives and improving interpersonal relations. Accordingly, this study makes horticultural therapy applied to the learning theories based on behaviorism, cognitivism, and constructivism establish itself in the integrated vocational education base school and help students with intellectual disabilities stand on their own and choose their careers. 


\section{Research Methods}

\section{Research scope}

\section{Location}

This study is conducted at an integrated vocational education base school of a general high school located in OO-dong, OO-si.

\section{Subjects}

Among 60 students in the first through third years of special classes in 6 schools of OO-si, OO-gun and OO-gun using the special class of the integrated vocational education base school, the control group consisted of 20 students (11 male, 9 female) who did not participate in horticultural therapy, and the experimental groups consisted of students who participated from each school. Moreover, this study selected 20 students (17 male, 3 female) with horticultural therapy not applying the learning theories, and 20 students ( 8 male, 12 female) with horticultural therapy applying the learning theories based on behaviorism, cognitivism, and constructivism.

\section{Design and tools}

\section{Design and program}

To verify the effects of horticultural therapy on improving interpersonal relations necessary for vocational skills, this study conducted a quasi-experiment to compare the difference in improvement of interpersonal relations among the control group not participating in the horticultural therapy program, the experimental group with the horticultural therapy program not applying the learning theories and the experimental group with the program applying the learning theories (Table 1).

The horticultural therapy program was carried out at the horticultural activity site located in OO-dong, OO-si that is the integrated vocational education base school, with 1 horticultural therapist and 2 special education teachers from each school. Considering that the subjects are high school students with intellectual disabilities, the special education teachers assisted their activities during the program. Total 12 sessions of the program were carried out every week, 3 hours each in the morning or afternoon, for the experimental group of the 6 schools from April 9 to June 29, 2012.

\section{Tools}

1) Diagram of the horticultural therapy program

This study was conducted to operate an effective horticultural therapy program reflecting the characteristics of high school students with intellectual disabilities focusing on the integrated vocational education base school. To this end, it systemized and consecutively applied the teaching methods based on behaviorism, cognitivism, constructivism that are the three perspectives of learning theories, thereby forming a program applying the theories as shown in Table 2 and

Table 1. Experimental design

\begin{tabular}{llll}
\hline Control & $\mathrm{O}_{1}$ & & $\mathrm{O}_{2}$ \\
Experimental 1 & $\mathrm{O}_{1}$ & $\mathrm{X}_{1}$ & $\mathrm{O}_{2}$ \\
Experimental 2 & $\mathrm{O}_{1}$ & $\mathrm{X}_{2}$ & $\mathrm{O}_{2}$ \\
\hline
\end{tabular}

$\mathrm{X}_{1}=$ Horticultural therapy not applying learning theories; $\mathrm{X}_{2}=$ Horticultural therapy applying learning theories based on behaviorism, cognitivism, and constructivism; $\mathrm{O}_{1}=$ Pre-test; $\mathrm{O}_{2}=$ Post-test. 
Table 2. Horticulture therapy program contents applying learning theory of behaviorism, cognitivism, and constructivism

\begin{tabular}{|c|c|c|c|c|c|c|c|}
\hline \multicolumn{8}{|c|}{ Program syllabus } \\
\hline \multirow[b]{2}{*}{ Lesson } & \multirow[b]{2}{*}{ Time } & \multirow[b]{2}{*}{ Title } & \multirow[b]{2}{*}{ Content } & \multicolumn{3}{|c|}{ Horticultural therapy applying learning theory } & \multirow{2}{*}{$\begin{array}{l}\text { Horticultural } \\
\text { therapy } \\
\text { not applying } \\
\text { learning theory }\end{array}$} \\
\hline & & & & $\begin{array}{l}\text { Direct instruction } \\
\quad(\text { Session } 1)\end{array}$ & $\begin{array}{l}\text { Discovery learning } \\
\quad \text { (Session 2) }\end{array}$ & $\begin{array}{c}\text { Cooperative learning } \\
\text { (Session } 3)\end{array}$ & \\
\hline Lesson 1 & $3 \mathrm{hr}$ & $\begin{array}{l}\text { Orientation } \\
\text { "Finding } \\
\text { Myself" }\end{array}$ & $\begin{array}{l}\text { *After introducing } \\
\text { oneself by using } \\
\text { Orange and ex- } \\
\text { pressing oneself } \\
\text { through the five } \\
\text { senses, they pick a } \\
\text { plant for a } \\
\text { nickname. }\end{array}$ & $\begin{array}{l}\text { *Put an orange in a } \\
\text { wrapped box to } \\
\text { feel the orange } \\
\text { with five senses. A } \\
\text { horticultural thera- } \\
\text { pist demonstrates } \\
\text { by example with } \\
\text { action. }\end{array}$ & $\begin{array}{l}\text { *Draw a picture } \\
\text { about 'Who I am' } \\
\text { through the orange } \\
\text { on a questionnaire } \\
\text { titled 'Finding } \\
\text { Myself' }\end{array}$ & $\begin{array}{l}\text { *Talk to each other } \\
\text { about a plant they } \\
\text { like through the } \\
\text { picture, share opin- } \\
\text { ions with others, } \\
\text { and then pick a } \\
\text { nickname for } \\
\text { oneself. }\end{array}$ & $\begin{array}{l}\text { *After wrapping an } \\
\text { orange in a box, } \\
\text { ask the recipients } \\
\text { what kind of pres- } \\
\text { ent is in a package } \\
\text { assuming one got } \\
\text { it from the post } \\
\text { office. After get- } \\
\text { ting the present, } \\
\text { express one's feel- } \\
\text { ings and pick a fa- } \\
\text { vorite plant for } \\
\text { one's nickname. }\end{array}$ \\
\hline Lesson 2 & $3 \mathrm{hr}$ & $\begin{array}{l}\text { Understanding } \\
\text { horticulture } \\
\text { "Making a } \\
\text { Human Tree" }\end{array}$ & $\begin{array}{l}\text { *Talk about five } \\
\text { senses from the } \\
\text { last lesson } \\
\text { *Find one's pressed } \\
\text { flower nametag } \\
\text { through a game. } \\
\text { Read one's own } \\
\text { nickname and put } \\
\text { the nametag in a } \\
\text { newspaper-flower } \\
\text { hat that they made. } \\
\text { Learn other } \\
\text { friend's name by } \\
\text { playing Drop the } \\
\text { Hat game. } \\
\text { *Label necessary } \\
\text { environmental con- } \\
\text { ditions on a friend } \\
\text { playing a role of a } \\
\text { plant tree. }\end{array}$ & $\begin{array}{l}\text { *Show a nametag } \\
\text { prepared in ad- } \\
\text { vance and learn } \\
\text { how to say their } \\
\text { own name and } \\
\text { nickname. }\end{array}$ & $\begin{array}{l}\text { *Look at plant pic- } \\
\text { tures and find } \\
\text { one's nickname } \\
\text { plant, then make a } \\
\text { newspaper-flower } \\
\text { hat and put the pic- } \\
\text { ture on it. Pick up } \\
\text { pictures of neces- } \\
\text { sary environmental } \\
\text { factors for said } \\
\text { plant. }\end{array}$ & $\begin{array}{l}\text { *While playing the } \\
\text { hat game, learn } \\
\text { about others by } \\
\text { reading out nick- } \\
\text { name pictures and } \\
\text { the counter-party's } \\
\text { name. } \\
\text { *When talking to a } \\
\text { friend who is play- } \\
\text { ing the role of a } \\
\text { human tree, one } \\
\text { will stick a note } \\
\text { containing neces- } \\
\text { sary factors for } \\
\text { growth and devel- } \\
\text { opment onto their } \\
\text { friend. }\end{array}$ & $\begin{array}{l}\text { *Find a nametag } \\
\text { and read out the } \\
\text { nickname, then } \\
\text { memorize the } \\
\text { name by playing } \\
\text { the hat game. } \\
\text { *Players write down } \\
\text { necessary environ- } \\
\text { mental factors for a } \\
\text { human tree. }\end{array}$ \\
\hline Lesson 3 & $3 \mathrm{hr}$ & $\begin{array}{l}\text { Horticulture } \\
\text { sympathy } \\
\text { "Decorating a } \\
\text { Veranda } \\
\text { Garden" }\end{array}$ & $\begin{array}{l}\text { *Talk about neces- } \\
\text { sary environmental } \\
\text { factors of plants } \\
\text { from the last } \\
\text { lesson. } \\
\text { *Learn about the } \\
\text { concept of gardens, } \\
\text { take favorite gar- } \\
\text { den pictures, and } \\
\text { create one's own } \\
\text { garden with them. } \\
\text { *Lastly, handle } \\
\text { plants and plant } \\
\text { them in the pot at } \\
\text { the veranda. }\end{array}$ & $\begin{array}{l}\text { *Observe the school } \\
\text { garden, being able } \\
\text { to speak about the } \\
\text { concept of a } \\
\text { garden. }\end{array}$ & $\begin{array}{l}\text { *Look at pictures } \\
\text { and also snap one's } \\
\text { own photos, then } \\
\text { create one's own } \\
\text { garden. }\end{array}$ & $\begin{array}{l}\text { *Choose three dif- } \\
\text { ferent types of } \\
\text { plants, plant them } \\
\text { in the pot at the ve- } \\
\text { randa, help each } \\
\text { other and talk } \\
\text { about the name of } \\
\text { plants. } \\
\text { *Learning that it is } \\
\text { more beautiful and } \\
\text { harmonious when } \\
\text { people are being } \\
\text { together than } \\
\text { alone. }\end{array}$ & $\begin{array}{l}\text { *After talking about } \\
\text { the school garden, } \\
\text { choose three dif- } \\
\text { ferent types of } \\
\text { plants and plant } \\
\text { them in the pot at } \\
\text { the veranda. } \\
\text { *Learning that it is } \\
\text { more beautiful and } \\
\text { harmonious when } \\
\text { plants are together } \\
\text { than only one. }\end{array}$ \\
\hline
\end{tabular}


Figure 1 to improve basic horticultural knowledge and interpersonal relations for vocational skills.

2) Procedures of the horticultural therapy program

In cutting, for example, the horticultural therapist described the materials in Session 1 (direct instruction) such as rose herbs, rosemary, ivy, pearlite, cutting box and scissors, and had the subjects touch, smell and name the plants by stimulating the five senses of humans. The researchers then clearly demonstrated the cutting of slips, planting and watering. This method is a direct instruction method based on the learning theory of behaviorism, applying a specific and direct method considering the learning abilities of students with intellectual disabilities.

In Session 2 (discovery learning), students were to understand the concepts on their own by seeing the materials and method of cutting in the form of images, and reading, writing and saying the names of the materials. Moreover, they were to develop inquiry skills and attitude in finding their own way by showing the procedures in pictures or images in detail. This method is discovery learning based on the theory of cognitivism, which is used to increase voluntary participation of students with intellectual disabilities and improve their inquiry skills by having them realize the concepts and principles on their own.

In Session 3 (cooperative learning), students were presented with actual materials and were to repeatedly say the names of the materials and touch them. Then they were to cut, plant and water the slips on designated areas in cooperation with other members of their teams, which are formed according to the working methods perceived in advance. This helped students realize that they can cooperate with others to achieve a shared goal, and that other students are not competitors but collaborators to help and cooperate with. This method is cooperative learning based on the learning theory of constructivism, and it was used to enable students with disabilities in the integrated class to actively participate in class, form actual integration, and learn and achieve collective goals or tasks (Figure 1).

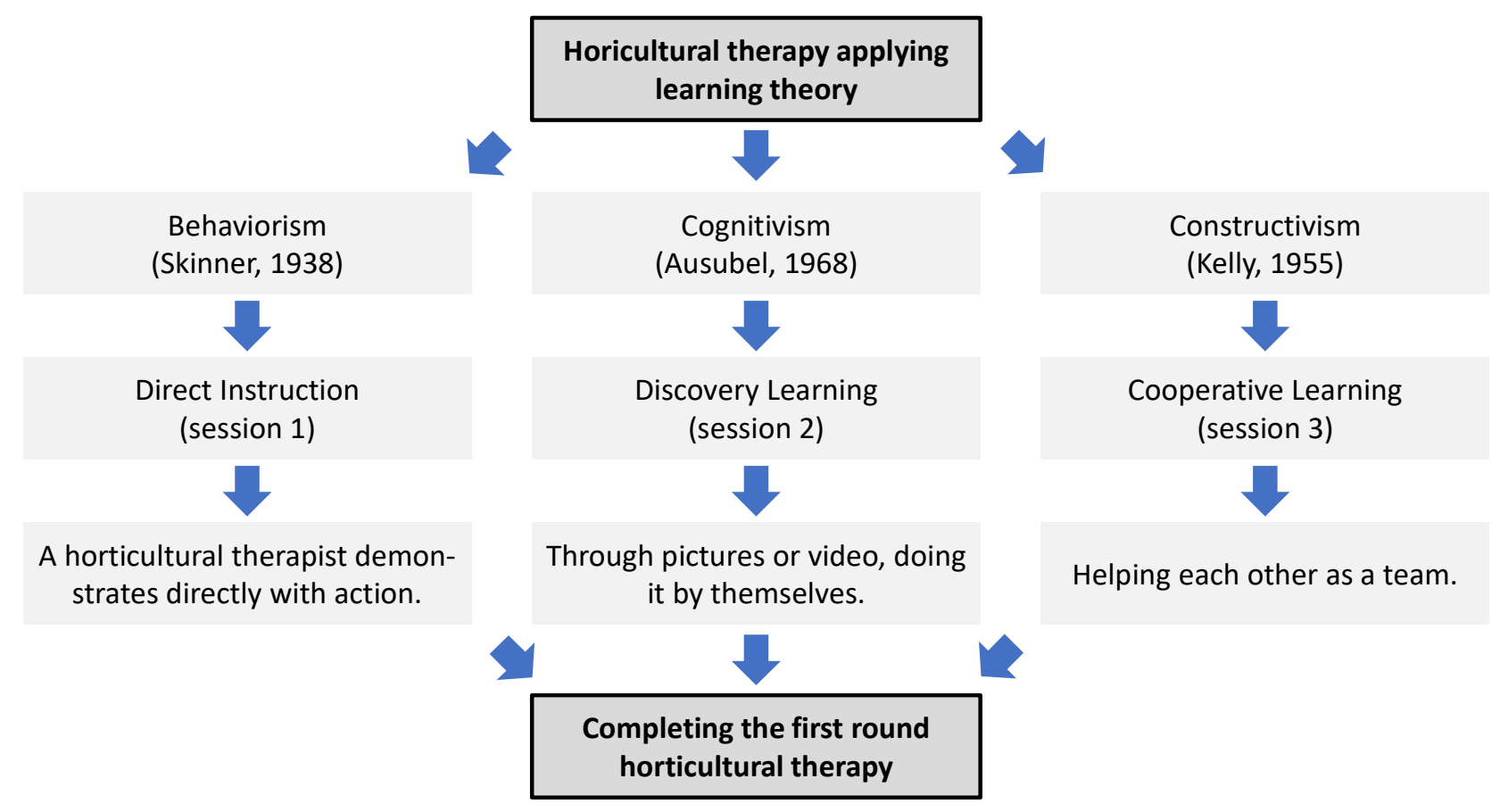

Figure 1. Composition diagram of horticulture therapy program applying learning theory of behaviorism, cognitivism, and constructivism. 


\section{3) Evaluation tool}

To measure interpersonal strategies, this study used the tool developed in 1987 by Beardslee, Schultz, and Selman (as cited in Kwon, 1988) and adapted by Kwon (1988). This scale was rated by the subjects themselves, and Levels 0-3, 0-1 are negative statements and 2-3 are positive statements, adding up to total 20 items that are rated on a five-point scale according to specific strategies (4 points: strongly disagree, 3 points: generally disagree, 2 points: somewhat agree, 1 point: generally agree, 0 point: fully agree). The items were scored by reverse operation on the negative statements of items 1 through 10, while items 11 through 20 are positive statements and were thus given the same scores as the scale.

4) Method of analysis

Data collected in this study were statistically analyzed using SPSS 12.0. ANOVA was conducted to test the homogeneity of groups before the program, and the paired sample t-test was conducted to compare the control group and experimental groups before and after the program. To compare the differences among the three groups after the experiment, ANOVA and multiple t-tests were conducted. The significance level was set at 5\% to test statistical significance.

\section{Results and Discussion}

\section{Homogeneity test}

The statistical results of Table 3 show that the control group and experimental groups are homogeneous without a significant difference before the program.

As a result of the homogeneity test before horticultural therapy, the control group had the mean of 31.9 , horticultural therapy not applying the learning theories had the mean of 29.3 and that applying the learning theories had the mean of 25.7, all of them not showing statistical significance and thereby homogeneous (Table 3).

The difference $(p=.27)$ in the intergroup and within-group mean of samples in the three groups is greater than the significance level $(p=.05)$ before the program, and thus the three groups are homogeneous (Table 4 ).

Table 3. Preliminary homogeneity test in interpersonal relationship tendencies among three groups

\begin{tabular}{lc}
\hline Group & Total item score M \pm SD \\
\hline Control & $31.9 \pm 2.15$ \\
${\text { Experimental } 1^{\mathrm{z}}}^{\text {Experimental 2 }}$ & $29.3 \pm 2.96$ \\
\hline
\end{tabular}

${ }^{\mathrm{z}}$ : Experimental group with the horticultural program not applying the learning theories

${ }^{\mathrm{y}}$ : Experimental group with the horticultural therapy applying the learning theories based on behaviorism, cognitivism and constructivism

Table 4. Preliminary analysis of variance in interpersonal relationship tendencies among three groups

\begin{tabular}{lccccc}
\hline \multirow{2}{*}{ Item } & \multicolumn{3}{c}{ ANOVA } & F & MS \\
\cline { 2 - 5 } & SS & df & 197.2 & 1.33 & .27 \\
\hline inter-group & 394.4 & 2 & 148.1 & & \\
intra-group & 8298.5 & 56 & & \\
total & 8692.9 & 58 & & \\
\hline
\end{tabular}




\section{Comparison before and after the horticultural therapy program}

A paired samples t-test was conducted to compare the difference before and after the horticultural therapy program in horticultural therapy applying the learning theories based on behaviorism, cognitivism, and constructivism and horticultural therapy not applying the learning theories.

The control group did not show significance after the program, and neither did the group with horticultural therapy not applying the learning theories. The group with horticultural therapy applying the learning theories based on behaviorism, cognitivism, and constructivism also did not show statistical significance (Table 5).

However, there was a difference in the intergroup change in the intergroup comparison of the three groups before and after the program. The improvement of interpersonal relations after the program in the three groups did not show significance between the control group and the group with horticultural therapy not applying the learning theories, but there was significance $(p=.03)$ between the control group and the group with horticultural therapy applying the learning theories (Table 6).

These results are similar to the findings of other studies claiming that horticultural therapy reduces anxiety of high school students with intellectual disabilities in special classes and regains their self-esteem (Jung, 2002), and that horticultural therapy based on the theory of behavior modification improves concentration and sociality (B.Y. Kim, 2010), thereby improving skills (Lee, 2010) and providing the opportunity to express themselves (Cho, 2011) and that horticultural therapy applying the learning theory of constructivism is effective for interpersonal relations and sociality (Lee, 2012), and horticultural education like actual experience have effects of vocational education such as technical training by repeating horticultural activities, employment and job creation by obtaining new knowledge (Lee, 2006).

In particular, high school students with intellectual disabilities in special classes lack problem solving skills, responsibility and social skills, and vocabulary and speaking ability in reproducing information, thereby having difficulty

Table 5. Pre and post paired t-test in interpersonal relationship improvements in three groups

\begin{tabular}{|c|c|c|c|c|}
\hline \multirow{2}{*}{ Group } & \multicolumn{2}{|c|}{$\mathrm{M} \pm \mathrm{SD}$} & \multirow{2}{*}{$\mathrm{t}$} & \multirow{2}{*}{$p$} \\
\hline & Pre-Horticultural therapy program & Post-Horticultural therapy program & & \\
\hline Control & $31.9 \pm 2.15$ & $31.9 \pm 2.15$ & & \\
\hline Experimental $1^{\mathrm{z}}$ & $29.3 \pm 2.96$ & $29.7 \pm 2.82$ & -0.12 & .45 \\
\hline Experimental $2^{\mathrm{y}}$ & $25.7 \pm 3.14$ & $22.5 \pm 2.89$ & 1.07 & .15 \\
\hline
\end{tabular}

${ }^{\mathrm{z}}$ : Experimental group with the horticultural program not applying the learning theories

${ }^{\mathrm{y}}$ : Experimental group with the horticultural therapy applying the learning theories based on behaviorism, cognitivism and constructivism

Table 6. Post multiple t-test in interpersonal relationship improvements between groups

\begin{tabular}{|c|c|c|c|c|c|}
\hline \multirow{2}{*}{ Division } & \multicolumn{5}{|c|}{ Multiple comparisons } \\
\hline & Group1 & Group2 & Mean difference & SE & $p$ \\
\hline \multirow{3}{*}{$\begin{array}{l}\text { Tukey HSD } \\
\text { (Honestly Significant } \\
\text { Difference) }\end{array}$} & Control & Experimental $1^{\mathrm{z}}$ & 2.22 & 3.74 & .82 \\
\hline & Control & Experimental $2^{\mathrm{y}}$ & 9.45 & 3.70 & $.03^{*}$ \\
\hline & Experimental 1 & Experimental 2 & 7.23 & 3.74 & .14 \\
\hline
\end{tabular}

${ }^{\mathrm{z}}$ : Experimental group with the horticultural program not applying the learning theories

${ }^{\mathrm{y}}$ : Experimental group with the horticultural therapy applying the learning theories based on behaviorism, cognitivism and constructivism

*Significant at $\mathrm{p}<.05$ 
making academic achievement on their own and limitation in vocational skills for careers. However, horticultural therapy applying learning theories based on behaviorism (direct instruction), cognitivism (discovery learning) and constructivism (cooperative learning) showed more desirable results than other horticultural activities or the control group, thereby proving that it is a program useful for improving interpersonal relations when applied to high school students with intellectual disabilities.

Based on the results, this study will make the following suggestions so that horticultural therapy applying the learning theories based on behaviorism, cognitivism, and constructivism will be established as a program to improve interpersonal relations necessary for vocational skills of high school students with intellectual disabilities.

As constantly receiving horticultural therapy proves to improve interpersonal relations, there must be follow-up research to change the perception of teachers and students with intellectual disabilities so that this program can be continued in the integrated vocational education base school. Moreover, there must be more active research on horticultural therapy programs to develop the naturalist intelligence among various types of human intelligence.

We are assured that horticultural therapy can be an essential requirement for well-rounded education of human begins as the fundamental goal of schools, and that it is necessary to make multiple efforts to actively implement horticultural therapy to school settings by developing various programs to promote horticultural therapy at integrated vocational education base schools.

\section{Conclusion}

The horticultural therapy program applying learning theories based on behaviorism, cognitivism, and constructivism in the integrated vocational education base school lays stress on improving interpersonal relations necessary for future independence and vocational skills of integrated education.

On the contrary, if high school students with intellectual disabilities receiving education with ordinary students perceive that they are different and lose confidence, this may cause a problem in forming interpersonal relations. Thus, this study focused on the fact that building interpersonal relations during this time is more important for them to have interest in future jobs and adapt to relationships with ordinary students.

The results of this study did not show statistically significant difference between the experimental group with horticultural therapy not applying the learning theories and the experimental group with horticultural therapy applying learning theories based on behaviorism, cognitivism, and constructivism ( $p=.15$ ). But the mean decreased from 25.7 to 22.45, showing a slight decrease of three points. Meanwhile, there was a statistically significant difference between the control group and the experimental group with horticultural therapy applying learning theories based on behaviorism, cognitivism, and constructivism ( $p=.03$ ), thereby proving that it is more effective for students with intellectual disabilities.

There was also a change in students that participated in the horticultural therapy not applying the learning theories, but the change was smaller than those that participated in the horticultural therapy applying the learning theories based on behaviorism, cognitivism, and constructivism.

\section{References}

Ausubel, D.P. 1968. Educational psychology: a cognitive view. New York: Holt, Rinehart and Winston.

Cho, I.Y. 2011. Horticultural therapy in adolescents with intellectual disabilities on self-expression and creativity. Master's thesis, Catholic University of Daegu, Daegu, Korea.

Cho, S.H. 2005. The effects of augmentative and alternative communication intervention on communicative means and 
communicative functions of children with severe mental retardation. Master's thesis, Daegu University, Gyeongbuk, Korea.

Choi, C.W. 1981. A study on the traits of motor ability in down syndrome. Master's thesis, Hansa University, Daegu, Korea.

Choi, H.J. 2004. Studies completion of the mathematics education consideration for the extension. -Around the discovery study and reception study-. Master's thesis, Chung-Ang University, Seoul, Korea.

Joo, B.S. 2013. Application of hydroponics program for improving work adjustment skills in students with mental retardation. Master's thesis, Konkuk University, Seoul, Korea.

Jung, H.J. 2002. Effect of horticultural therapy on the changes of self-esteem and anxiety of the mentally retarded students in high school. Master's thesis, Konkuk University, Seoul, Korea.

Jung, Y.A. 2011. Effect of horticultural therapy based upon self-determination enhancement model on the improvement of self-determination ability and learning achievement for under-achieving middle school students. Master's thesis, Konkuk University, Seoul, Korea.

Kang, G.Y. 2004. The effects of horticultural therapy on vocational adaptability of the intellectual disabled. Master's thesis, Korea University, Seoul, Korea.

Kelly, G.A. 1955. The psychology of personal constructs. New York: Norton.

Kim, B.Y. 2010. Horticultural therapy based on B.F.Skinner's behavior modification for the improvement of the attention and sociality for intellectual disability children. Master's thesis, Konkuk University, Seoul, Korea.

Kim, H.D. 2011. Study on the teaching process through a comparison of discovery learning and interpretative teaching -under the content of differentiation-. Master's thesis, Keimyung University, Daegu, Korea.

Kim, H.S. 2017. An Investigation on cooperative teaching methods through utilization of constructivism. Master's thesis, Chung-Ang University, Seoul, Korea.

Kim, J.Y. 2003. A study on efficiency progress in mathematics lesson conducted through discovery learning - Focusing on a chapter of "measurement" of a solid figure targeting students in the 1st grade of junior high school -. Master's thesis, Kookmin University, Seoul, Korea.

Kim, K.L. 2010. Memorizing model of effective English study: applying Ebbinghaus forgetfulness periodic theory. Master's thesis, Dankook University, Seoul, Korea.

Kim, S.Y. 2010. The effect that the period gap of repetitive learning has on learning attitude. Master's thesis, Kookmin University, Seoul, Korea.

Kwon, H.S. 1988. The Effects of socio-dramatic play on social competence of mentally retarded. Master's thesis, Dankook University, Seoul, Korea.

Lee, E.S., S.H. Sim, and K.C. Son. 2002. Effect of horticultural therapy on interpersonal negotiation strategies of mentally retarded persons. J. Korean Soc. People Plants Environ. 5(2):17-24.

Lee, K.M. 2004. A study on the understanding and developing capability of Iconic mode of representation of elementary school students in the fourth grade in fraction learning emphasizing EIS theory. Master's thesis, Ewha Womans University, Seoul, Korea.

Lee, S.J. 2011. An analysis on effect of horticultural therapy program for improving of vocational adjustment of mentally disabled people. Master's thesis, Hansung University, Seoul, Korea.

Lee, S.J. 2012. The development and application of horticultural therapy introduced learning theory of constructivism -focused on vocational training for adolescents with intellectual disabilities-. Doctoral dissertation, Dankook University, Seoul, Korea.

Lee, S.J., S.M. Lee, and J.K. Suh. 2012. The conceptual frame of horticultural therapy as vocational training(H.T.V.T.) for adolescents with intellectual disabilities. J. Korean Soc. People Plants Environ. 15(5):307-318.

Lee, S.M. 2006. An analysis of the effects of horticultural therapy to each client and the economic value by income approach. Doctoral dissertation, Dankook University, Seoul, Korea.

Lee, Y.J. 2010. Apply of horticultural therapy program on the improvement behavioral characteristics in youth with 
intellectual disability. Master's thesis, Korea University, Seoul, Korea.

Noh, J.Y. 2016. The effects of horticultural therapy on reducing bullying, depressive feelings, anxiety and stress and promoting resilience for Adjustment among teenagers. Master's thesis, University of Seoul, Seoul, Korea.

Park, J.Y. 2006. Horticultural therapeutic model presentation to the mentally retarded. Master's thesis, Dankook University, Seoul, Korea.

Skinner, B.F. 1938. The behavior of organisms: an experimental analysis. Oxford, England: Appleton-Century.

Son, M.R. 2015. Effect of horticultural therapy on school life adaptation and stress of juvenile. Doctoral dissertation, Wonkwang University, Iksan, Korea.

Suh, J.K. and S.M. Lee. 2004. The application and practice of horticultural therapy process for horticultural therapist. Cheonan, Korea: Dankook University Press. 